and one of its most active collaborators, was in 1972, but the real work began in August 1973 at St Nizier near Grenoble during a meeting prepared and organized by Félix. Already at this meeting and later at the various 'Aachen meetings' in 1977-1979, the spirit was 'high': the various national 'schools' of crystallography clashed over such issues as trigonal versus rhombohedral and monoclinic $c$-axis versus $b$-axis setting (the so-called 'monoclinic monster'). Félix, with his sharp and critical mind, stayed above such 'professorial politics', realising quickly the merits but also the shortcomings of a proposed solution. Fortunately, after the working hours, international friendship was restored by 'vin rouge et fromage'.

Félix Bertaut's contributions to Volume A are noteworthy and will not be forgotten. He wrote Chapter 4 on 'Synoptic Tables of Space-Group Symbols' with extended Hermann-Mauguin symbols, many interesting and individualistic examples of group-subgroup relations and historic recourses to former editions of International Tables. As a second contribution, Yves Billiet and he wrote Chapter 13 on 'Isomorphic Subgroups of Space Groups', opening the way to the treatment of this infinite set of subgroups in the actual spacegroup tables. Beyond these special topics, he has contributed greatly to the success of the entire volume by quick recognition of novel ideas and old errors.

As a German, this writer wants to stress that Félix Bertaut was an unusually strong and successful advocate of the FrenchGerman cooperation and friendship in science and among scientists after the last world war. This is not only obvious from Félix's contribution to neutron diffraction and the establishment of the ILL in Grenoble, but also from numerous visits in Germany, as well as personal contacts and support of young scientists. For these efforts he is highly respected in both countries.

I want to close this reminiscence of our friend Félix on a humerous note (which would be quite in his spirit), quoting a few passages from his letters which illuminate the personal and human side of this wonderful man.
(On his 80th birthday:) 'For the group of order 80 , I must tell you that I prefer 90 , but it will take more time than the International Tables.'

'Le secret de la jeunesse d'esprit, en accord avec un collègue danois, c'est une action difficile à définir, mais facile à identifier.' (The secret of mental youth, according to a Danish colleague, is a phenomenon difficult to define, but easy to identify.)

'Reiselust ist eine Krankheit, die nur durch noch mehr Reisen geheilt werden kann.' (Travel urge is a desease which can be cured only by more travelling.)

\section{Theo Hahn}

Institut für Kristallographie der RWTH,

Aachen, Germany

(Editor of Volume A of International Tables

for Crystallography)

\section{Sivaraj Ramaseshan (1923-2003)}

Sivaraj Ramaseshan, distinguished crystallographer, materials scientist and much else, died at Bangalore on 29 December, 2003, at the age of 80 , after a prolonged illness. $\mathrm{He}$ leaves behind his wife Kausalya and three daughters.

Born in Kolkata (formerly Calcutta) on 10 October, 1923, he graduated from the University of Nagpur before joining the great scientist C. V. Raman in the Physics Department of the Indian Institute of Science in 1943. After obtaining his doctorate, he continued as a faculty member in the Department. His early work was concerned with magnetism and optics. He turned to crystallography in the first half of the fifties and quickly established a vibrant crystallographic group at Bangalore. Among the many contributions that emanated from the group, particular mention may be made of the two-wavelength method for solving crystal structures using anomalous disper- sion, which in fact forms the basis for the currently hugely popular multiple anomalous dispersion (MAD) method. He moved to the Indian Institute of Technology, Madras, in 1962, where he continued his crystallographic researches. While at IIT, he spent a year in Dorothy Hodgkin's laboratory at Oxford, which marked the beginning of several life-long friendships.

He returned to Bangalore in 1966, now to start a materials science laboratory at the National Aeronautics Laboratory. This turned out be the beginning of his outstanding contributions in the area and their use for important applications. $\mathrm{He}$ continued to pursue fundamental research in physics and crystallography as well. In addition to the work in his own laboratory, he contributed to the development by other institutions of products such as heart valves, blood bags and components for aerospace applications. He was appointed as Joint Director of the Indian Institute of Science in 1979 and Director in 1981, from which position he formally retired in 1984. During his second tenure at the Institute, he initiated several important scientific and technological programmes.

His post-retirement phase proved to be extremely productive and useful. He was deeply involved in the administration of the Indian Academy of Sciences, of which he was President during 1983-1985, and the Raman Research Institute, Bangalore. He took a keen interest in Academy publications, particularly the journal Current Science, of which he was editor from 1989 until his death. Particular mention must also be made of the publication by the Academy of the collected works of Dorothy Hodgkin, which he coedited, in three volumes.

Ramaseshan has been honoured with many fellowships and awards. He served the International Union of Crystallography in several capacities, including as its VicePresident (1981-1984). Remarkably, a substantial proportion of crystallographers in India are his academic descendents.

\section{Vijayan}

Molecular Biophysics Unit, Indian Institute of Science, Bangalore 560 012, India 